\title{
Correspondence
}

British Heart fournal, 1975, 37, 1202-1204.

\section{Isolated ventricular inversion with situs solitus}

Sir:

Drs. Quero-Jiménez and Raposo-Sonnenfeld recently described two examples of an anomalous heart characterized by the association of atrioventricular discordance with what they consider to be normally related great arteries (British Heart fournal, 1975, 37, 293-304). They term the anomaly 'isolated ventricular inversion' and rightly give precedence in its description to Van Praagh and Van Praagh (1966). While the atrioventricular discordance in the cases described is unequivocal, we would take issue with them regarding the ventriculoarterial relation, which they designate as normal.

The authors themselves suggest that a differential diagnosis would be mirror-image dextrocardia, i.e. situs inversus, atrioventricular concordance with normally related great arteries. They then correctly indicate that in this situation the normally positioned aorta would be left-sided and posterior. Since this statement indicates that a left-sided aorta is normal for 1-bulboventricular looping (the concordant loop in the inversus individual) it seems illogical to describe the right-sided aorta in the cases presented as being normally related, since an l-loop is also present in these hearts. Surely the right-sided posterior aorta is only normally related in the presence of situs solitus and atrioventricular concordance. We are unable to accept that this relation is normal in the presence of situs solitus and 1-looping merely because of the presence of aortic-mitral fibrous continuity. As the authors indicate, if the aortic and mitral valves were separated by conal musculature, anatomically corrected malposition (malposition rather than transposition, Van Praagh et al., 1971) would be present.

Van Praagh and his colleagues (197I) demonstrated clearly that transposition could exist in the presence of aortic-mitral fibrous continuity. Why then cannot anatomically corrected malposition also exist with aortic-mitral continuity ? Van Praagh et al. (1975) have more recently documented examples of this anomaly without a subpulmonary conus. We would contend that it is more logical to consider the ventriculoarterial relation described by Drs.
Quero-Jiménez and Raposo-Sonnenfeld as anatomically corrected malposition with absorption of the subaortic conus, conal absorption now being a well documented embryological fact (Goor, Dische, and Lillehei, 1972; Anderson et al., 1974). It is our belief that acceptance of this ventriculo-arterial relation as anatomically corrected malposition would clarify this difficult subject, and would permit discarding the confusing term 'isolated ventricular inversion'.

Robert H. Anderson,
Department of Paediatrics,
Cardiothoracic Institute,
Brompton Hospital,
London, SW3 6HP.
James L. Wilkinson,
Institute of Child Health,
University of Liverpool,
Alder Hey Children's Hospital,
Liverpool, Li2 2AP.

This letter was shown to Dr. Quero-Jiménez who replies as follows:

\section{Sir:}

I. Position of the great arteries. Throughout our paper we stated on several occasions that, in this entity, there is a normal position of the great arteries, inasmuch as the aorta emerges posteriorly and to the right with respect to the pulmonary artery (Fig. c). Nowhere in the paper have we written that 'the ventriculoarterial relation is normal'. I have no doubt in saying that the ventriculoarterial relation present in this entity is an abnormal one, for the aorta and the pulmonary artery originate from rightsided and left-sided ventricles respectively, contrary to the norm.

2. Position of the great arteries with respect to the situs of the individual. I believe that in the cases reported in this paper the most reliable frame of reference should be the general constitution of the individual, that is to say, these 2 patients have situs solitus of the viscera and atria, and normally placed lungs, liver, stomach, intestines, etc. In them, the ventricles are the only structures which are inverted 


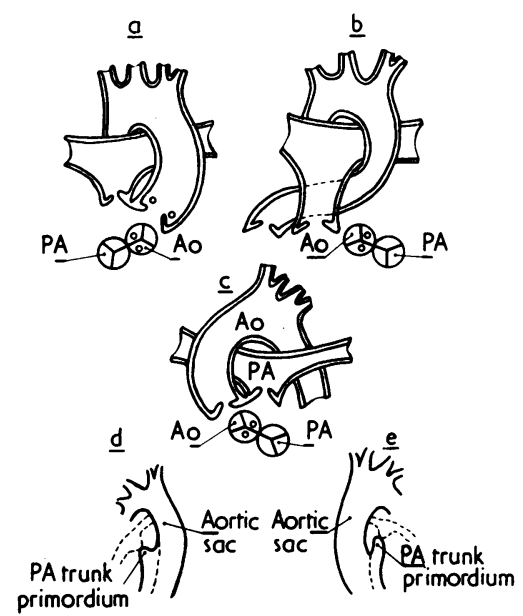

FIG. a) Expected position of the great arteries in L-loop cases.

b) Expected position of the great arteries in isolated ventricular inversion cases if it was due to the rotation of the heart around its longitudinal axis alone.

c) Actual position of the great arteries in isolated ventricular inversion cases.

d) Right-sided location of the PA trunk primordium in L-loop cases with a left-sided (concordant) aorta.

e) Left-sided location of the PA trunk primordium in L-loop cases with a right-sided (discordant) aorta: isolated ventricular inversion cases.

\section{Ao, aorta; $P A$, pulmonary artery.}

with respect to the normal. Consequently, I do not think that we should take the ventricles as a frame of reference. On the other hand, I quite agree with Dr. Anderson that in both patients there is a discrepancy between the position of the ventricles and great arteries, a fact expressed on page 304 (second paragraph, right column). This same paragraph states that in this malformation there is inversion of the great arteries with respect to the bulboventricular loop, inasmuch as in cases with an l-bulboventricular loop, the aorta is expected to be situated to the left of the pulmonary artery (Fig. I). The reason why in these cases the aorta is situated to the right of the pulmonary artery cannot be explained on the basis of the rotation of the heart around its longitudinal axis alone, because if that was the case the great arteries would appear abnormally twisted one around the other (Fig. b). It is our opinion that this discrepancy between the bulboventricular loop and the great arteries can be explained only on the basis of inversion in the situation of the protuberance of the aortic sac. This then gives rise to the main pulmonary artery which would be a right-sided structure in usual cases of l-loop (Fig. d) and a leftsided structure (just as in the usual d-loop cases) in cases of isolated ventricular inversion with situs solitus (Fig. e). I should say that this interpretation is the result of a discussion held with Dr. Van Praagh and my Spanish colleagues, Drs. Pérez Martínez and Casanova in Boston, Massachusetts, and with Dr. Van Mierop in Gainsville, Florida.

3. Is aortic-mitral fibrous continuity a reason for considering the arterial relation as normal? It is obvious that in the 2 cases reported in this paper there was an aortic-mitral fibrous continuity, but this fact has in no way been used as an argument in favour of a normal position of the great arteries.

4. Terminology: Isolated ventricular inversion. Anatomically corrected transposition. Anatomically corrected malposition. It is well known to me that cases of transposition of the great arteries with aortic-mitral valvar fibrous continuity may exist. I was the author of the initial publication of this entity (Quero Jiménez, Pérez Martínez, and Moreno Granados, I969). I was, too, a collaborator in the second paper (Van Praagh et al., I97I). With respect to the terminology, I understand Dr. Anderson's reasoning and I am not against what he is proposing. I have used the traditional terminology to make it easier, I think, for colleagues to localize these anomalies using the same name that was used in previous descriptions of the same disease (Van Praagh and Van Praagh, 1966; Martinez Picó and Muñoz, 1967; Pérez Treviño, Hurtado del Río, and Holden, 1972).

In general, I prefer to keep the traditional terminology unless an international committee of experts, after a careful study and consideration of the pros and cons, strongly advises the acceptance of different and new terms.

It is obvious, anyway, that for all of us our main interest should be not terminology but the most accurate description and plausible interpretation of the actual facts that are possible.

$$
\begin{aligned}
& \text { M. Quero-Jiménez, } \\
& \text { Jefe del Servicio de } \\
& \text { Cardiología Pediátrica, } \\
& \text { Clínica Infantil 'La Paz', } \\
& \text { Madrid, Spain. }
\end{aligned}
$$

\section{References}

Anderson, R. H., Wilkinson, J. L., Arnold, R., and Lubkiewicz, K. (1974). Morphogenesis of bulboventricular malformations. I. Consideration of embryogenesis in the normal heart. British Heart fournal, 36, 242.

Goor, D. A., Dische, R., and Lillehei, C. W. (1972). The conotruncus. I. Its normal inversion and conus absorption. Circulation, 46, 375. 
Martínez Picó, A., and Muñoz, A. (1967). Inversión ventricular: transposición fisioloógica de la circulación y relación aorto-pulmonar normal. Boletín de la Asociación médica de Puerto Rico, 59, 26.

Pérez Treviño, C., Hurtado del Río, D., and Holden, A. M. (1972). Inversión ventricular aislada. Archivos del Instituto de Cardiología de México, 42, 966.

Quero Jiménez, M., Pérez Martínez V., and Moreno Granados, F. (1969). Variantes de D-transposición de los grandes vasos según el tipo y la localización del cono muscular. Referata Pediátrica, 9, 63.

Van Praagh, R., Durnin, R. E., Jockin, H., Wagner, H. R. Korns, M., Garabedian, H., Ando, M., and Calder, A. L.
(1975). Anatomically corrected malposition of the great arteries $\{\mathrm{S}, \mathrm{D}, \mathrm{L}\}$. Circulation, 5I, 20.

Van Praagh, R., Perez-Trevino, C., Lopez-Cueller, M., Baker, F. W., Zuberbuhler, J. R., Quero, M., Perez, V. M., Moreno, F., and Van Praagh, S. (197I). Transposition of the great arteries with posterior aorta, anterior pulmonary artery, subpulmonary conus and fibrous continuity between aortic and atrioventricular valves. American fournal of Cardiology, 28, $62 \mathrm{I}$.

Van Praagh, R., and Van Praagh, S. (1966). Isolated ventricular inversion. A consideration of the morphogenesis, definition and diagnosis of nontransposed and transposed great arteries. American fournal of Cardiology, 17, 395. 